\title{
Trophic relationships between primary producers and associated fauna in a pristine Cerrado pond
}

\author{
Elisa A.C.C. ALVIM,${ }^{1 *}$ Tiago B. KISAKA,${ }^{1}$ Gabriela B. NARDOTO,${ }^{1}$ Luciana DE MENDONÇA-GALVÃO,${ }^{2}$ \\ Barbara M. FONSECA, ${ }^{2}$ Mercedes M.C. BUSTAMANTE ${ }^{1}$
}

${ }^{1}$ Departamento de Ecologia, Universidade de Brasília; ${ }^{2}$ Curso de Biologia, Universidade Católica de Brasília, Brazil

\begin{abstract}
Ponds arising from groundwater in Cerrado of Central Brazil are oligotrophic but highly biodiverse environments. In this study, we used stable isotope ratios to test if there are variations in carbon and nitrogen acquisition by different primary food sources and if they are influenced by seasonality in a well-preserved pond. We hypothesized that periphyton is the main food source for macrophyteassociated fauna. We found that $\delta^{13} \mathrm{C}$, but not $\delta^{15} \mathrm{~N}$, can distinguish between primary food sources; however, the isotopic signatures of food sources did not differ significantly between seasons. The $\delta^{15} \mathrm{~N}$ values of macrophyte-associated fauna were significantly higher for predators compared with other trophic groups, but $\delta^{13} \mathrm{C}$ values did not differ significantly between groups. Emergent macrophytes and periphyton were the main food sources for scrapers (contribution of $42.5 \%$ ) and collector-gatherers (contribution of $41.6 \%$ ), respectively. Compared with emergent macrophytes, submerged macrophytes were associated with a greater abundance of fauna and algal biomass but were not a significant food source for associated fauna. Our findings demonstrate that in this small shallow oligotrophic pond in the Cerrado, the stable isotope ratios of carbon and nitrogen of food sources did not vary between seasons but did differ between aquatic macrophyte life forms. We point out the different functional roles of macrophyte life forms, with emergent macrophytes serving as an important food resource, while submerged macrophytes mainly provide physical structure
\end{abstract}

\section{INTRODUCTION}

.Trophic webs are macrodescriptors of nutritional interactions within a community and can be used to map the flow of energy and matter (Jepsen and Winemiller, 2002). Identifying the basis of trophic webs is fundamental for understanding the dynamics of populations, communities, and ecosystems. According to Lopes and Benedito-Cecílio (2002), the understanding of energy flow within ecosystems starts with investigating processes that occur with primary producers and exploring how nutritional variability at this level influences higher trophic levels. In tropical lentic environments, the structure of the trophic web may be influenced by changes in the availability of carbon sources due to precipitation patterns and variations in primary

Corresponding author: elisa.alvim@gmail.com

Key words: Periphyton; aquatic macrophytes; stable isotopes; trophic web; oligotrophic.

Edited by: Giampaolo Rossetti, University of Parma, Italy.

Received: 28 November 2018

Accepted: 5 July 2019.

This work is licensed under a Creative Commons Attribution NonCommercial 4.0 License (CC BY-NC 4.0).

${ }^{\circ}$ Copyright: the Author(s), 2019

Licensee PAGEPress, Italy

J. Limnol., 2019; 78(3): 310-322

DOI: 10.4081/jlimnol.2019.1874 productivity (Reis et al., 2016; Saigo et al., 2016). Furthermore, trophic dynamics may be affected by the presence of different types of primary producers. The cooccurrence of various food resources may result in more complex pathways for energy transfer (Vadeboncoeur et al., 2005; Vander Zanden et al., 2011). According to Doi (2009), autochthonous and allochthonous resource availability in lakes is influenced by light, nutrient level, and terrestrial subsidies. These factors also contribute substantially to variation in trophic structure across ecosystems.

Stable isotopes of carbon and nitrogen are important tools to study trophic webs in aquatic ecosystems (Arcagni et al., 2013; Mendonça et al., 2013; Lopes et al., 2015; Iglesias et al., 2017). Stable isotope analysis plus understanding of natural history of organisms and of species interactions lead to the most thorough understanding of food webs (Layman et al., 2007). The use of stable isotopes is based on the premise that isotopic ratios are conservative tracers and that a combination of distinct sources determines the flow of nutrients between organisms (Fry, 2006). The isotopic signature of carbon $\left(\delta^{13} \mathrm{C}\right)$ can distinguish between autotrophic energy sources, whereas the isotopic signature of nitrogen $\left(\delta^{15} \mathrm{~N}\right)$ can distinguish between trophic levels, with $\delta^{15} \mathrm{~N}$ is enriched, on average, 3-4\% per trophic level (Peterson, 1999; Eggers and Jones, 2000). Moreover, seasonality can affect environmental factors and modify $\delta^{13} \mathrm{C}$ and $\delta^{15} \mathrm{~N}$ of the basal resources. This has been described by Alves et al. (2017) for $\mathrm{pH}$ and nutrient concentrations in a Neotropical floodplain and by Mao et al. (2014) for temperature, irradiance, and terrestrial input of carbon and nitrogen in a shallow eutrophic lake in China.

Because lentic systems are resistant to gas diffusion and 
there is the formation of boundary layers, aquatic plants are adapted to the lower availability of $\mathrm{CO}_{2}$ and oxygen (Chambers et al., 2008). The available carbon source is the main factor responsible for differences in the $\delta^{13} \mathrm{C}$ values of macrophytes (Finlay and Kendall, 2007). Primary producers in aquatic systems have more than one source of inorganic carbon $\left(\mathrm{CO}_{2}\right.$ and/or $\left.\mathrm{HCO}_{3}^{-}\right)$; therefore, a large range of $\delta^{13} \mathrm{C}$ signals is possible within the ecosystem, complicating carbon source tracing (Mendonça et al., 2013). Compared with pelagic producers, littoral producers experience less turbulence and have a thicker boundary layer, and are therefore enriched in $\delta^{13} \mathrm{C}$ (France, 1995). According to Chappuis et al. (2017), the assimilation of $\mathrm{HCO}_{3}{ }^{-}$in addition to $\mathrm{CO}_{2}$, results in $\delta^{13} \mathrm{C}$ signals more enriched compared with plants exclusively using $\mathrm{CO}_{2}$. The functional group of aquatic plants is an important intrinsic factor determining $\delta^{13} \mathrm{C}$ variability.

Natural shallow ponds are widely distributed in Cerrado biome, presenting numerous plant species with different morphologies whose physical structure promotes considerable habitat heterogeneity in such ecosystems (Sousa et al., 2014). The dominant taxa in these ecosystems are algae (periphyton and metaphyton), aquatic macrophytes, protozoa, and an impressive diversity of invertebrates, mainly Cladocera species (Bini et al., 2007; Sousa et al., 2014; Fonseca and Estrela, 2015; Fonseca et al., 2017). Pond size is related to the length and width of the littoral zone, which displays the best ecological conditions in terms of oxygen and temperature (de Marco Jr et al., 2014). In these natural shallow ponds of the Cerrado, water levels vary from 20 to around $80 \mathrm{~cm}$ (Fonseca et al., 2017), it is not possible to delimit a pelagic zone.

In this study we investigated trophic relationships in a natural shallow pond in the Cerrado that is colonized by aquatic macrophytes (submerged and emergent). The following hypotheses were tested: i) submerged macrophytes are enriched in $\delta^{13} \mathrm{C}$ compared with other food resources because of differential fractionation during the uptake of dissolved inorganic carbon; ii) food resources (periphyton and submerged/emergent macrophytes) have similar $\delta^{15} \mathrm{~N}$ values because nitrogen sources do not show a high degree of variability; iii) seasonality affects the carbon and nitrogen stable isotope ratios of food resources because of changes in water temperature and $\mathrm{pH}$; and iv) periphyton is the main food source for macrophyte-associated fauna because of its lower carbon:nitrogen $(\mathrm{C}: \mathrm{N})$ ratio.

\section{METHODS}

\section{Study area}

The study was carried out at Henrique Pond $\left(15^{\circ} 41^{\prime} 17^{\prime \prime} \mathrm{S} 47^{\circ} 56^{\prime} 25^{\prime \prime} \mathrm{W}\right)$, which is a shallow oligotrophic pond of approximately 2.9 ha (total phosphorus: $13.0 \mu \mathrm{g} / \mathrm{L}$;
Fonseca et al., 2017). The pond is located in the Brasilia National Park of the Federal District of Brazil, which is the largest conservation unit (42,389 ha) in the Federal District in the category of total protection. The park's aquatic ecosystems are part of the Upper Paraná River Basin. More than $80 \%$ of the pond's surface is covered by aquatic macrophytes (Sousa et al., 2014). The main water sources are groundwater outcropping and precipitation. The terrain slope permits water accumulation, reaching a depth of 1.2 $\mathrm{m}$. According to the National Meteorological Institute (http://www.inmet.gov.br/portal/), total annual precipitation for the year 2015 was $1252.7 \mathrm{~mm}$. In this study we obtained samples during two seasons of 2015: the rainy season (October to March, total precipitation of $975.2 \mathrm{~mm}$ ) and the dry season (April to September, total precipitation of $277.5 \mathrm{~mm}$ ).

\section{Limnological variables}

An in situ evaluation was performed in each collection site in both seasons to determine water temperature (Oximeter YSI 55), water depth, dissolved oxygen concentration (Oximeter YSI 55), pH (Digimed MD 20), and electrical conductivity (Minipa MCD-2000). To analyze turbidity and alkalinity, $1 \mathrm{~L}$ water was collected and transported to the laboratory in an insulated container. Turbidity analysis (Hach 2100 AN) was carried out the day of sampling while, and alkalinity was analyzed the following day using the Gram method (Carmouze, 1994).

\section{Macrophyte survey}

To determine which macrophyte species would be used to evaluate trophic relationships, samples were collected in two perpendicular zones (1 m wide), extending across the longest and the widest parts of the pond, totaling $410 \mathrm{~m}^{2}$. All macrophytes within these zones were collected, stored in plastic bags, and kept in an insulated box until transport to the laboratory on the same day. In the laboratory the macrophytes were washed with distilled water and a soft brush to remove adherent periphyton and then separated for identification. The macrophytes were lyophilized for $72 \mathrm{~h}$ and ground with a pulverizing mill (Planetary Mill Pulverisette 5, Fritsch) to produce a fine powder for isotopic analysis.

\section{Food sources and sediment for evaluation of isotopic signatures}

After we surveyed all macrophytes in the two collection zones, we selected one morphospecies of the emergent macrophytes belonging to the Cyperus $\mathrm{L}$. genus (Cyperaceae), and one morphospecies of the submerged macrophytes belong to the Cabomba Aubl. genus (Cabombaceae) to evaluate trophic relationships. These macrophytes were chosen because they have different life 
patterns and are abundant in the pond throughout the year (personal observation). Emergent and submerged macrophytes were sampled in five different sites, resulting in 10 plots for season. The plots were at least $3 \mathrm{~m}$ apart from each other and were selected based on the presence of macrophytes. A $20 \mathrm{~cm}^{\prime} 20 \mathrm{~cm}$ square frame was used in order to standardize the sampling. This procedure was repeated during both rainy and dry seasons.

Mature vegetative parts that were submerged were collected and stored in plastic bags. Young and senescent plants were avoided to focus on a single successional stage of the periphyton community. The macrophytes were frozen after washed with $300 \mathrm{~mL}$ deionized water and softly brushed to collect the associated periphyton. The $300 \mathrm{~mL}$ water was filtered using a $250-\mu \mathrm{m}$ mesh to remove large detritus and macroinvertebrates; $100 \mathrm{~mL}$ of the filtered water was used to analyze periphyton chlorophyll-a (Marker et al., 1980; Sartory and Grobblelar, 1984), $100 \mathrm{~mL}$ was used to determine ash-free dry mass (AFDM) (APHA, 2005), and $100 \mathrm{~mL}$ was used for isotopic analysis of the periphyton.

When present, metaphyton, here represented by filamentous algae, was collected by filtering the water through a steel sieve with a $20-\mu \mathrm{m}$ mesh. The collected material was frozen in Falcon tubes for further analysis.

Additionally, sediment was collected using a Kajaktype gravity core sampler at a depth of $0-20 \mathrm{~cm}$. In the laboratory, macrophytes and roots were removed before homogenizing the sediment, which was then frozen in 50$\mathrm{mL}$ Falcon tubes.

\section{Macrophyte-associated fauna}

Macrophyte-associated fauna was collected by dragging a plankton net $(100-\mu \mathrm{m}$ mesh) through the aquatic vegetation within a $2-\mathrm{m}$ radius at each collection site $(\mathrm{n}=5$ for each type of macrophyte [submerged (Cabomba) vs emergent (Cyperus)], for a total of 10 samples in each season). The samples were fixed in alcohol (final concentration, $70 \%$ ). Organisms within each sample were identified at the level of the family for insect larvae, order for microcrustaceans, and class for other organisms. Organisms were then classified according to functional trophic group, as previously described (Elmoor-Loureiro, 1997; Ramírez and Gutiérrez-Fonseca, 2014). The individual organisms were frozen in Eppendorf tubes.

\section{Isotope analysis of food sources}

Frozen macrophyte and periphyton samples were lyophilized for $72 \mathrm{~h}$. The macrophyte samples were ground as described in the "Macrophyte survey" section, and the periphyton samples were macerated in Eppendorf tubes with glass beads using a high-velocity benchtop homogenizer (FastPrep-24). The frozen macrophyte-associated fauna samples were dried at $60^{\circ} \mathrm{C}$; organisms larger than $1 \mathrm{~cm}$ were ground in a mortar and pestle, and organisms smaller than $1 \mathrm{~cm}$ were used intact for isotope analysis.

It was necessary to combine samples according to family and season to obtain the minimum mass necessary for isotopic analysis. The fauna associated with macrophytes and periphyton were weighed (minimum of $1.5 \mathrm{mg}$ and $0.9 \mathrm{mg}$, respectively) in an analytical balance and placed in tin capsules. Isotopic analyses were carried out by the Isotopic Ecology Laboratory in the Center Nuclear Energy in Agriculture (University of São Paulo, Piracicaba, Brazil). Samples were processed by combustion under a continuous flow of ultrapure helium in an elemental analyzer (Carlo Erba CHN 1110) coupled to a Thermo Finnigan Delta Plus mass spectrometer.

The results were expressed in delta notation $(\delta)$, in parts per thousand (\%) relative to standard international references (Vienna Pee Dee Belemnite from the Grand Canyon, USA, for $\mathrm{C}$; atmospheric air for $\mathrm{N}$ ) and were calculated using the following equation: $\delta \mathrm{X}=(\mathrm{R}$ sample / R standard - 1) ' 1000 , where $\mathrm{X}$ is ${ }^{13} \mathrm{C}$ or ${ }^{15} \mathrm{~N}$, and $\mathrm{R}$ represents the isotopic ratios ${ }^{13} \mathrm{C} /{ }^{12} \mathrm{C}$ or ${ }^{15} \mathrm{~N} /{ }^{14} \mathrm{~N}$ in the sample or the standard. The acceptable analytic error was $\pm 0.3 \%$ and $0.3 \%$ for $\mathrm{C}$ and $\delta^{13} \mathrm{C}$, respectively.

\section{Statistical analysis}

Normality of the abiotic data was evaluated by using the Shapiro-Wilk test. Descriptive analysis of the abiotic data used the arithmetic mean as a measure of central tendency, and standard error (SE) as a measure of dispersion of the data. Student's $t$-test was used to compare limnological data between seasons when the data were normally distributed. Because electrical conductivity, dissolved oxygen, and periphyton AFDM data showed nonnormal distribution, we used the Wilcoxon test.

Seasonal differences between food sources and differences between emergent and submerged macrophytes and the associated periphyton were evaluated using Student's t-test when the dataset was homoscedastic and the residuals were normally distributed, otherwise the Mann-Whitney test was used.

Differences in $\delta^{13} \mathrm{C}, \delta^{15} \mathrm{~N}$, and $\mathrm{C}: \mathrm{N}$ values between the food sources were evaluated by 1 -factor analysis of variance (ANOVA) when the premises of dataset homoscedasticity and normal distribution of residuals were accepted. Welch's test was used when the residuals were normally distributed, but the dataset was not homoscedastic, and the Kruskal test was used when neither premise was accepted. Seasonal differences in stable isotopes of food sources were evaluated using Tukey HSD (honest significance difference) test for normally distributed datasets, otherwise the Kruskal multiple comparison was used. Differences in $\delta^{13} \mathrm{C}$ and $\delta^{15} \mathrm{~N}$ values between primary consumers (collector- 
gatherers and scraper) and secondary consumers (predators) were evaluated by Student's $t$-test. Differences in associated fauna abundance between macrophyte type and between seasons were evaluated by 2-way ANOVA. For this study, $\mathrm{P}<0.05$ was considered significant. Normality was evaluated using the Shapiro-Wilk test, and homoscedasticity was evaluated using Levene's test. Statistical analyses were carried out using R software ver. 3.2.2 (R Core Team, 2015).

Bayesian mixing models using Stable Isotope Analysis in R (SIAR v. 4.0, Parnell et al., 2010) were used to estimate isotope incorporation by the associated fauna. The SIAR model is fit via Markov Chain Monte Carlo (MCMC) methods and takes the variability in source and consumers isotopic signatures. This approach estimates the proportional contribution of potential sources within the tissue of the consumer and we consider the carbon and nitrogen composition of the sources (Parnell et al., 2010).

Emergent macrophytes, submerged macrophytes, and periphyton were selected as potential food sources for primary consumers (collector-gatherers and scraper invertebrates). The collector-gatherers and scraper invertebrates were selected as potential food sources for predators. The food sources used in each calculation were selected with the consideration of the feeding mode of the consumers and availability in habitat. In our study, constant TEF values of $+0.4 \pm 1.23 \mathrm{SD} \delta 13 \mathrm{C}$ and $+2.3 \pm 1.61 \mathrm{SD} \delta 15 \mathrm{~N}$ were used. These values corresponded to the mean TEF estimates in aquatic ecosystems (McCutchan et al., 2003).

\section{RESULTS}

\section{Limnological variables}

In Henrique Pond, water temperature $\left(23.9 \pm 0.2^{\circ} \mathrm{C}\right)$ and water turbidity $(2.55 \pm .2 \mathrm{NTU})$ were significantly greater in the dry season, but the temperature difference from the rainy season $\left(22.7 \pm 0.1^{\circ} \mathrm{C}\right)$ was much less pronounced than the seasonal difference found for turbidity (rainy season $-0.9 \pm 0.1 \mathrm{NTU}$ ). The dissolved oxygen concentration $\left(6.6 \pm 0.1 \mathrm{mg} \mathrm{L}^{-1}\right)$ and depth $(0.9 \pm 0.04 \mathrm{~m})$ were greater in the rainy season but seasonal difference of dissolved oxygen was subtle (Tab. 1). Water depth in the dry season was $0.2 \mathrm{~m}$ lower. The other variables $(\mathrm{pH}$, electrical conductivity, alkalinity, periphyton chlorophyll- $a$, and AFDM) did not differ between seasons.

\section{Analysis of food sources, metaphyton and sediment}

Of the 12 species collected in the macrophyte survey, six were emergent and six were submerged (Tab. 2). Mean $\delta^{13} \mathrm{C}$ values differed significantly between emergent and submerged macrophytes $(-27.73$ and $-23.32 \%$, respectively; $\mathrm{t}=-4.32, \mathrm{P}=0.001)$, but $\delta^{15} \mathrm{~N}$ values did not differ significantly $(\mathrm{t}=-0.65, \mathrm{P}=0.533)$. These results were used to select the aquatic macrophyte species for the experiment.

Our results show that carbon and nitrogen stable isotope ratios of the food sources did not differ significantly between seasons (Tab. 3). Because of this lack of seasonal variation, samples collected in the dry and rainy seasons were combined to evaluate the stable isotope ratios of the food sources. We evaluated 10 samples of Cyperus sp. (five samples for each season), 9 samples of Cabomba sp. (five samples for rainy season plus four samples for dry season), 16 samples of periphyton (some samples presented enough mass for the analysis), five samples of metaphyton (collected when present), and six samples of sediment (three samples for each season).

Our results showed that food sources differed significantly with regard to $\delta^{13} \mathrm{C}$ values $\left(\mathrm{H}_{4}=28.2\right.$, $\mathrm{P}<0.001$; Fig. 1a). Food sources did not show significant

Tab. 1. Limnological variables of Henrique Pond, Brasilia National Park, Federal District, during the rainy and dry seasons of 2015. P values in bold represent significant differences.

\begin{tabular}{|c|c|c|c|c|c|}
\hline \multirow[t]{2}{*}{ Variable } & \multicolumn{2}{|c|}{ Rainy season } & \multicolumn{2}{|c|}{ Dry season } & \multirow[t]{2}{*}{$\mathbf{P}$} \\
\hline & Mean value \pm SE & CV & Mean value \pm SE & CV & \\
\hline Water temperature $\left({ }^{\circ} \mathrm{C}\right)$ & $22.7 \pm 0.1$ & 0.02 & $23.9 \pm 0.2$ & 0.03 & $<0.001$ \\
\hline Depth $(\mathrm{m})$ & $0.9 \pm 0.04$ & 0.13 & $0.7 \pm 0.06$ & 0.27 & 0.030 \\
\hline $\mathrm{pH}$ & $5.6 \pm 0.04$ & 0.02 & $5.5 \pm 0.05$ & 0.03 & 0.085 \\
\hline Electrical conductivity $\left(\mu \mathrm{S} \mathrm{cm}^{-1}\right)$ & $3.7 \pm 0.5$ & 0.43 & $3.9 \pm 0.2$ & 0.19 & 0.140 \\
\hline Dissolved oxygen $\left(\mathrm{mg} \mathrm{L}^{-1}\right)^{*}$ & $6.6 \pm 0.1$ & 0.04 & $5.8 \pm 0.1$ & 0.07 & 0.001 \\
\hline Turbidity (NTU) & $0.9 \pm 0.1$ & 0.46 & $2.5 \pm 0.2$ & 0.27 & $<0.001$ \\
\hline Alkalinity $\left(\mathrm{mg} \mathrm{CaCO}_{3} \mathrm{~L}^{-1}\right)$ & $1.6 \pm 0.1$ & 0.13 & $1.7 \pm 0.1$ & 0.14 & 0.460 \\
\hline Periphyton chlorophyll- $a\left(\mathrm{~g} \mathrm{~m}^{-2}\right)$ & $16.1 \pm 4.4$ & 0.86 & $12.2 \pm 2.9$ & 0.72 & 0.480 \\
\hline Periphyton ash-free dry mass $\left(\mathrm{g} \mathrm{m}^{-2}\right)^{*}$ & $0.006 \pm 0.002$ & 1.34 & $0.002 \pm 0.001$ & 0.91 & 0.722 \\
\hline
\end{tabular}

CV, coefficient of variation; * Wilcoxon test; NTU, nephelometric turbidity unit. 
difference for $\delta^{15} \mathrm{~N}$ values $\left(\mathrm{F}_{3,13}=1.4, \mathrm{P}=0.296\right)$, but differs significantly from sediment $\left(\mathrm{F}_{4,15}=5.6, \mathrm{P}=0.005\right.$; Fig. $\left.1 \mathrm{~b}\right)$. Sediment and the submerged macrophyte were more ${ }^{13} \mathrm{C}$ enriched than the other food sources. The mean $\delta^{13} \mathrm{C}$ and $\delta^{15} \mathrm{~N}$ values were $-25.59 \pm 0.20 \%$ and $0.84 \pm 0.68 \%$, respectively, for Cyperus sp.; $-21.20 \pm 0.30 \%$ and $0.40 \pm 1.15 \%$, respectively, for Cabomba sp.; $25.23 \pm 0.62 \%$ and $1.99 \pm 0.34 \%$, respectively, for periphyton; $-24.42 \pm 1.01 \%$ and $2.27 \pm 0.58 \%$, respectively, for metaphyton; and $-22.50 \pm 0.20 \%$ and $4.23 \pm 0.46 \%$, respectively, for sediment.

The C:N ratios of the food sources also differed significantly $\left(\mathrm{H}_{4}=7.2, \mathrm{P}<0.001\right.$; Fig. $\left.1 \mathrm{c}\right)$, with the lowest $\mathrm{C}: \mathrm{N}$ ratios for sediment $(11.9 \pm 0.2)$ and periphyton (12.1 \pm 0.5$)$, and the highest $\mathrm{C}: \mathrm{N}$ ratio for the emergent macrophyte Cyperus sp. (90.1 \pm 4.7$)$. Intermediate $\mathrm{C}: \mathrm{N}$ ratios were observed for metaphyton $(18.2 \pm 2.3)$ and the submerged macrophyte Cabomba sp. (28.3 \pm 1.1$)$.

The macrophytes differed significantly with regard to periphyton chlorophyll $a$ concentration $(\mathrm{W}=0, \mathrm{P}<0.001)$ and AFDM ( $\mathrm{W}=0, \mathrm{P}<0.001)$, with greater values observed for Cabomba sp. $\left(114.9 \mathrm{~g} / \mathrm{m}^{2}\right.$ and $0.212 \mathrm{~g} / \mathrm{m}^{2}$, respectively) (Fig. 2 a,b), despite the higher biomass of Cyperus sp. compared to Cabomba sp. (W=64, $\mathrm{P}<0.001$; Fig. 2c).

\section{Macrophyte-associated fauna}

The collection of macrophyte-associated fauna resulted in a total 3,983 individual organisms for analysis. Insects accounted for $78.2 \%$ of the macrophyte-associated fauna, and mites, microcrustaceans, and tadpoles were also present (Tab. S1). The sampled organisms were more often associated with the submerged macrophyte Cabomba sp. (in both seasons) and were more abundant in the dry season for both macrophytes studied $\left(\mathrm{F}_{1,16}=17.9\right.$, $\mathrm{P}<0.001)$.

\section{Isotopic analysis of macrophyte-associated fauna}

Despite the large number of individual organisms collected, it was not possible to carry out isotopic analysis for some taxa because of low overall mass. Isotopic analysis was carried out for the following 11 taxa: Coenagrionidae, Dicteriadidae, Lestidae, Libellulidae, Tanypodinae, Ceratopogonidae, Chironominae, Culicidae, Hydroptilidae, Cladocera, and Anura (Tab. 4). As there were no statistical differences between the isotopic signatures for associated fauna in

Tab. 2. Isotopic signatures of carbon $\left(\delta^{13} \mathrm{C}, \%\right)$ and nitrogen $\left(\delta^{15} \mathrm{~N}, \%\right.$ o $)$ of all aquatic macrophytes collected in Henrique Pond, Brasilia National Park, Federal District, Brazil. These results were used to select the aquatic macrophyte species for the experiment.

\begin{tabular}{|c|c|c|c|}
\hline Habitat & Aquatic macrophyte & $\delta^{13} \mathrm{C}(\% 0)$ & $\delta^{15} \mathrm{~N}(\% 0)$ \\
\hline \multirow[t]{9}{*}{ Emergent } & CYPERACEAE & & \\
\hline & Cyperus sp. & -27.37 & 5.75 \\
\hline & Rhynchospora sp. & -29.84 & 3.06 \\
\hline & Morphospecies 1 & -25.97 & 1.65 \\
\hline & MELASTOMATACEAE & & \\
\hline & Morphospecies 1 & -29.22 & 2.22 \\
\hline & POACEAE & & \\
\hline & Otachyrium sp. & -25.33 & 2.28 \\
\hline & Panicum sp. & -28.65 & -0.96 \\
\hline \multirow[t]{9}{*}{ Submerged } & CABOMBACEAE & & \\
\hline & Cabomba sp. & -22.87 & 3.56 \\
\hline & MENYANTHACEAE & & \\
\hline & Nymphoides indica & -26.01 & 4.64 \\
\hline & Unidentified family & & \\
\hline & Morphospecies 1 & -23.66 & 2.95 \\
\hline & Morphospecies 2 & -23.63 & 1.00 \\
\hline & Morphospecies 3 & -23.07 & 0.89 \\
\hline & Morphospecies 4 & -20.67 & 5.49 \\
\hline
\end{tabular}

Tab. 3. Isotopic signatures of food sources collected during the rainy and dry seasons in Henrique Pond, Brasilia National Park, Federal District, Brazil.

\begin{tabular}{|c|c|c|c|c|c|}
\hline Food source & & Rainy $(\%)$ & Dry $(\%)$ & df & $\mathbf{P}$ \\
\hline \multirow[t]{2}{*}{ Cyperus sp. (emergent macrophyte) ${ }^{*}$} & $\delta^{15} \mathrm{~N}$ & 1.28 & 0.40 & 8 & 0.55 \\
\hline & $\delta^{13} \mathrm{C}$ & -25.95 & -25.24 & 8 & 0.06 \\
\hline \multirow[t]{2}{*}{ Cabomba sp. (submerged macrophyte) ${ }^{*}$} & $\delta^{15} \mathrm{~N}$ & 1.32 & -0.76 & 7 & 0.40 \\
\hline & $\delta^{13} \mathrm{C}$ & -21.55 & -20.77 & 7 & 0.19 \\
\hline \multirow[t]{2}{*}{ Periphyton } & $\delta^{15} \mathrm{~N}$ & 1.77 & 2.21 & 14 & 0.52 \\
\hline & $\delta^{13} \mathrm{C}$ & -25.62 & -24.84 & 14 & 0.55 \\
\hline \multirow[t]{2}{*}{ Metaphyton } & $\delta^{15} \mathrm{~N}$ & 2.61 & 1.77 & 3 & 0.55 \\
\hline & $\delta^{13} \mathrm{C}$ & -23.15 & -26.33 & 3 & 0.13 \\
\hline \multirow[t]{2}{*}{ Sediment } & $\delta^{15} \mathrm{~N}$ & 3.62 & 4.84 & 4 & 0.22 \\
\hline & $\delta^{13} \mathrm{C}$ & -22.38 & -22.62 & 4 & 0.62 \\
\hline
\end{tabular}

df, degrees of freedom; *for the macrophyte genera selected, we repeated the isotope analysis for each collection site and both seasons. All data were analyzed using Student's t-test. 
Tab. 4. Isotopic signatures $\delta^{13} \mathrm{C}$ and $\delta^{15} \mathrm{~N}$ of macrophyte-associated fauna in Henrique Pond, Brasilia National Park, Federal District, Brazil.

\begin{tabular}{|c|c|c|c|c|c|c|}
\hline Taxon & TFG & $\mathbf{N}$ & Mean $\delta^{13} \mathrm{C}(\%)$ & SD & Mean $\delta^{15} \mathbf{N}(\%)$ & SD \\
\hline Coenagrionidae & $\operatorname{Pr}$ & 5 & -24.97 & 1.61 & 5.17 & 1.00 \\
\hline Dicteriadidae & $\operatorname{Pr}$ & 1 & -25.68 & & 6.95 & \\
\hline Lestidae & $\operatorname{Pr}$ & 1 & -24.14 & & 7.22 & \\
\hline Libellulidae & $\operatorname{Pr}$ & 5 & -23.19 & 2.08 & 3.71 & 1.08 \\
\hline Tanypodinae & $\operatorname{Pr}$ & 8 & -24.17 & 1.88 & 4.09 & 1.01 \\
\hline Ceratopogonidae & $\operatorname{Pr}$ & 1 & -24.54 & & 3.69 & \\
\hline Chironominae & CG & 2 & -24.34 & & 3.75 & \\
\hline Culicidae & $\mathrm{CG}$ & 2 & -25.22 & & 3.74 & \\
\hline Hydroptilidae & $\mathrm{Sc}$ & 1 & -26.15 & & 1.69 & \\
\hline Cladocera & $\mathrm{Sc}$ & 1 & -25.24 & & 3.28 & \\
\hline Anura & $\mathrm{Sc}$ & 3 & -24.24 & 1.36 & 4.27 & 0.80 \\
\hline
\end{tabular}

TFG, trophic functional group, according to Ramírez and Gurriérez-Fonseca (2014); N, number of samples; CG, collector-gatherers; Pr, predators; Sc, scrapers. Data are expressed as mean $\pm S D$.
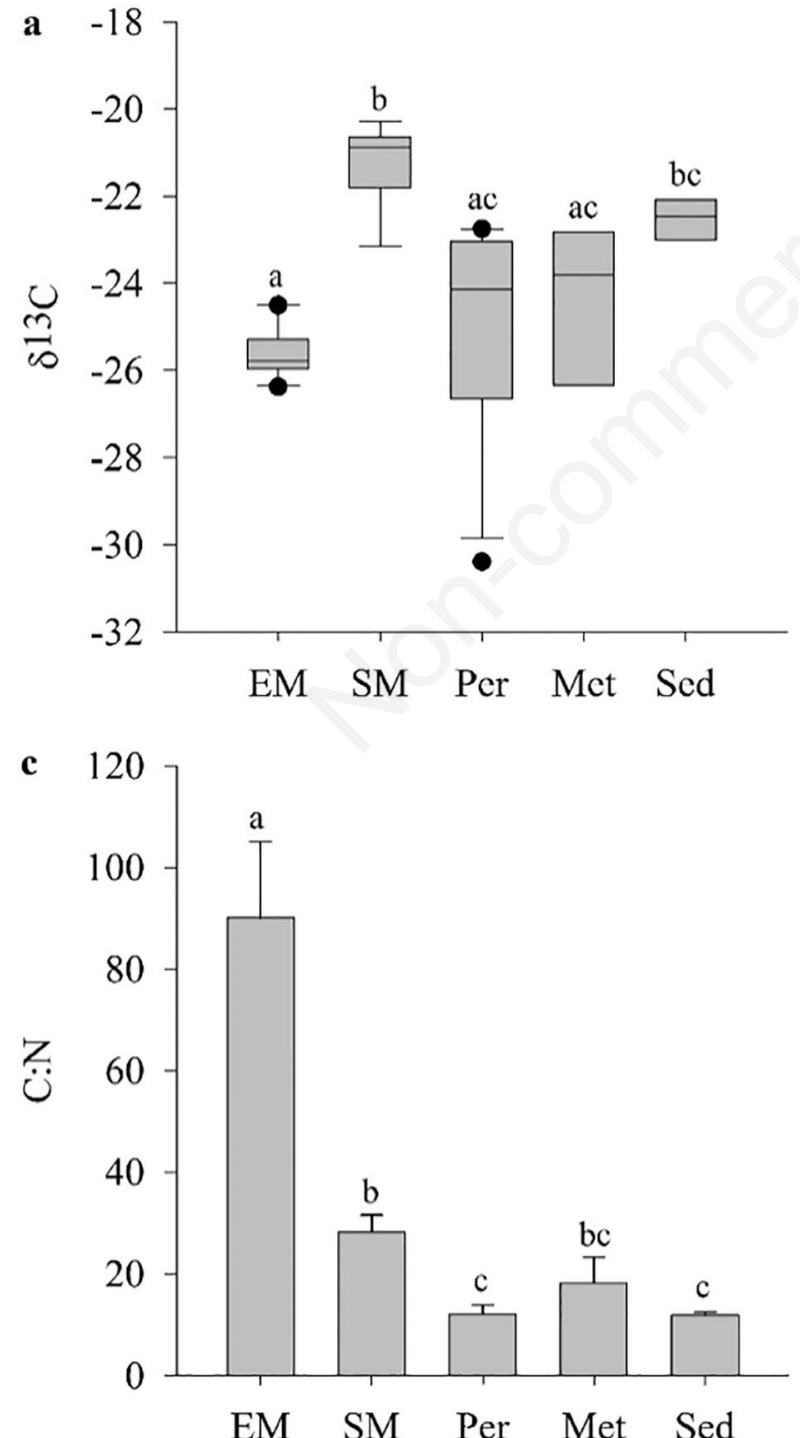

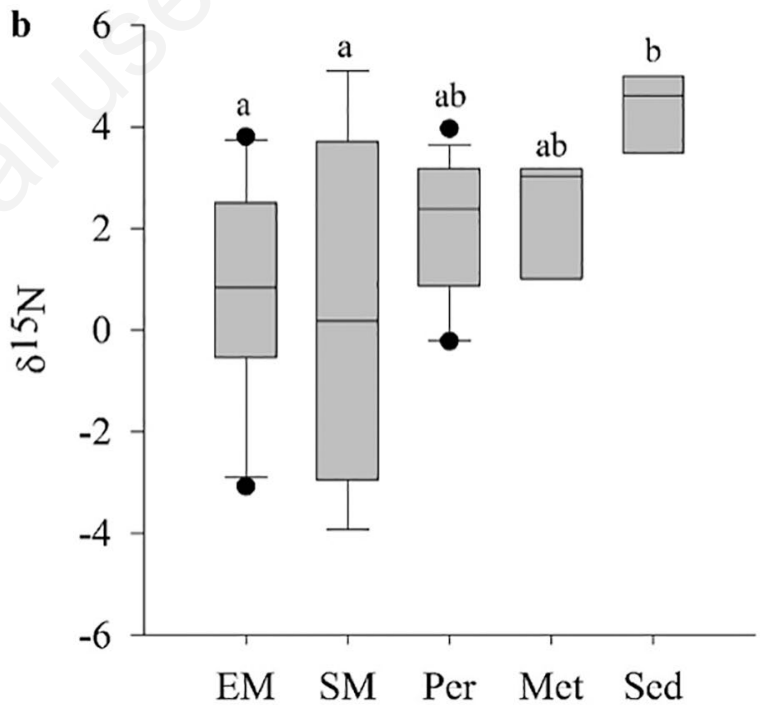

Fig. 1. Isotopic signatures of carbon (a) and nitrogen (b) and $\mathrm{C}: \mathrm{N}$ ratio (c) for the following food resources: emergent macrophyte Cyperus sp. (EM), submerged macrophyte Cabomba sp. (SM), periphyton (Per), metaphyton (Met), and sediment (Sed) in Henrique Pond, Brasilia National Park, Federal District, Brazil. Different superscript letters indicate significant differences $(\alpha=0.05)$. Results are expressed as mean \pm SE. 
the dry and rainy period $(\mathrm{t}=0.35, \mathrm{P}=0.725)$, samples were composed. Our results showed that $\delta^{13} \mathrm{C}$ values varied between -26.2 and $-24.1 \%$ for associated fauna but did not differ significantly between primary consumers (collector-gatherers and scraper) and secondary consumers (predators) $(\mathrm{t}=-0.92, \mathrm{P}=0.383$ ). However, $\delta^{15} \mathrm{~N}$ values were significantly higher in secondary consumers (mean value of 5.3\%) compared with primary consumers $(\mathrm{t}=-2.83, \mathrm{P}=0.020)$.

\section{Use of food sources by macrophyte-associated fauna}

For collector-gatherers, periphyton was the principal food source, with a proportional contribution of $41.6 \%$, followed by emergent macrophyte Cyperus sp. (38.6\%) and submerged macrophyte Cabomba sp. (19.7\%; Fig. $3)$. For scrapers, the emergent macrophyte Cyperus sp. a
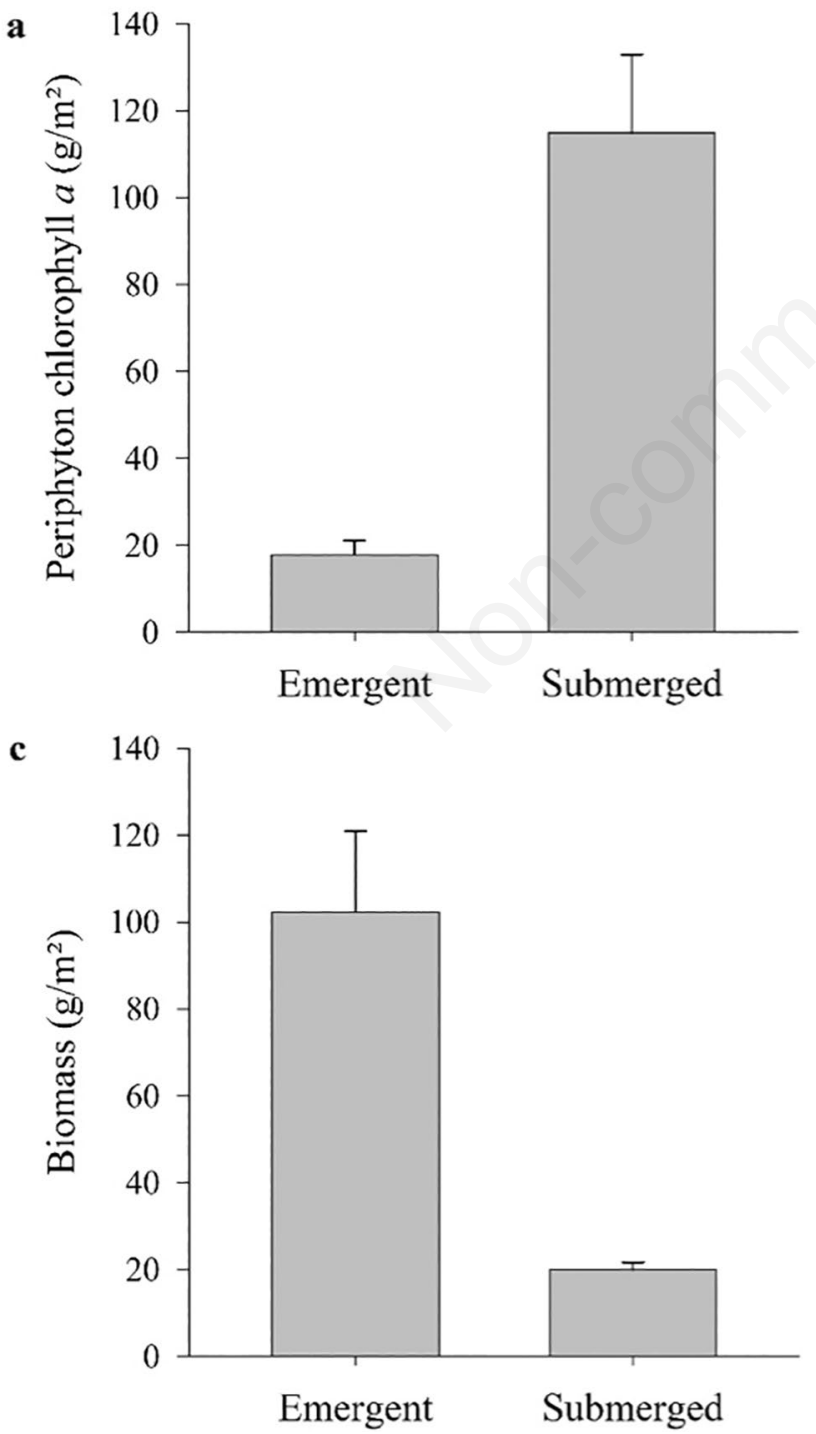

was the principal food source, with a proportional contribution of $42.5 \%$, followed by periphyton ( $40.0 \%)$ and the submerged macrophyte Cabomba sp. (17.5\%; Fig. 3). For predators, scrapers were the principal food source, with a contribution of $62.0 \%$. Scrapers were represented by three taxa: Cladocera, tadpoles and Hydroptilidae (Trichoptera), representing 27\% of the total richness and $13 \%$ of total abundance of the macrophyte-associated fauna.

Fig. 4 shows the carbon and nitrogen isotopic composition of macrophyte-associated fauna and their food sources. The $\delta^{13} \mathrm{C}$ isotopic signature of all fauna groups indicated higher consumption of the emergent macrophyte Cyperus sp., and periphyton. Secondary consumers (predators) showed more enriched $\delta^{15} \mathrm{~N}$ values than the primary consumers (for collectorgatherers and scrapers).

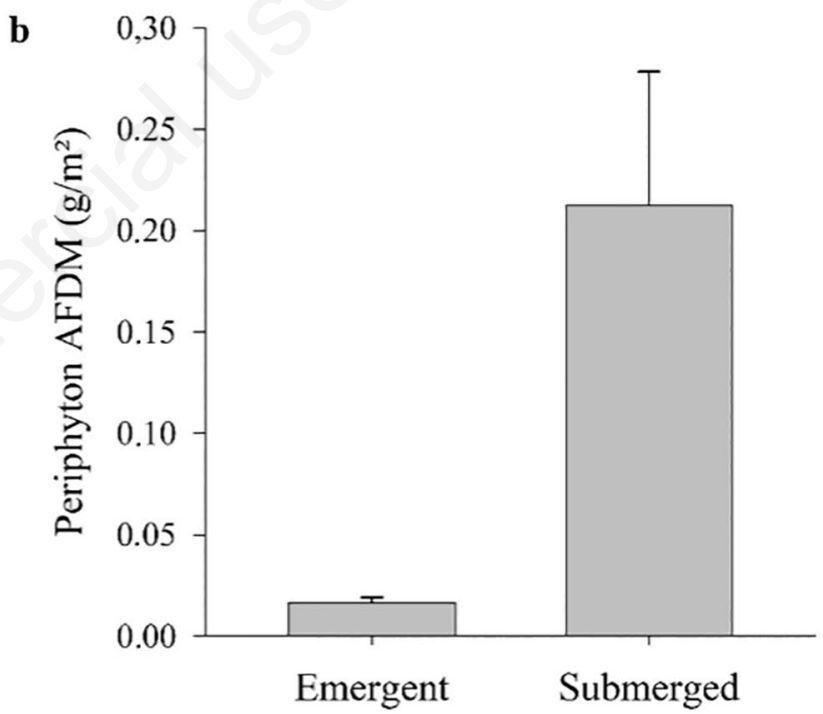

Fig. 2. Periphyton chlorophyll- $a$ concentration (a), periphyton ash-free dry mass (AFDM) (b), and biomass (c) of the emergent macrophyte Cyperus sp. and submerged macrophyte Cabomba sp. in Henrique Pond, Brasilia National Park, Federal District, Brazil. Results are expressed as mean \pm SE. 


\section{DISCUSSION}

Primary producers form the base of the trophic web in ecosystems, synthesizing organic compounds and providing nutrients for the other trophic levels. For Henrique Pond, the basal energy sources evaluated were macrophytes (emergent and submerged), macrophyte- associated periphyton, metaphyton, and sediment. In general, the primary carbon sources of this pond are isotopically similar to those of other tropical environments (Tab. 5).

The $\delta^{13} \mathrm{C}$ values for all sources were close to the mean value for $\mathrm{C}_{3}$ plants, except for Cabomba sp. that showed enrichment of $\delta^{13} \mathrm{C}$, confirming the first hypothesis (i.e.,

Tab. 5. Comparison of isotopic signatures $\delta^{13} \mathrm{C}(\%)$ and $\delta^{15} \mathrm{~N}(\%)$ of food sources between studies of tropical environments and the present study.

\begin{tabular}{|c|c|c|c|}
\hline Source & Range $\delta^{13} \mathrm{C}(\%)$ & Range $\delta^{15} \mathbf{N}(\%)$ & Reference \\
\hline Emergent macrophytes & -28.6 to -27.4 & -0.9 to 5.7 & Current study \\
\hline Emergent macrophyte Cyperus sp. & -26.4 to -25.5 & -3.1 to 3.8 & Current study \\
\hline Submerged macrophytes & -22.9 to -20.7 & 0.9 to 5.5 & Current study \\
\hline Submerged macrophyte Cabomba sp. & -23.1 to -20.3 & -3.9 to 5.1 & Current study \\
\hline $\mathrm{C}_{3}$ macrophytes & -31 to -27 & 4 to 9.5 & Wantzen et al., 2002 \\
\hline Emergent macrophyte (Eleocharis interstincta) & -30.2 to -28.9 & -1.3 to 5.1 & Reis et al., 2016 \\
\hline Aquatic macrophytes & -33 to -24 & 1 to 3 & Iglesias et al., 2017 \\
\hline Periphyton & -30.4 to -22.8 & -0.2 to 4.0 & Current study \\
\hline Periphyton & -33 to -26 & 1 to 3 & Wantzen et al., 2002 \\
\hline Periphyton & -26.9 to -18.4 & 4.1 to 5.6 & Reis et al., 2016 \\
\hline Sediment & -23.2 to -21.8 & 2.1 to 5.2 & Current study \\
\hline Sediment & -38 to -27 & 1 to 5.7 & Wantzen et al., 2002 \\
\hline Sediment & -33.1 to -31.2 & 1.8 to 3.5 & Reis et al., 2016 \\
\hline Metaphyton & -28.2 to -22.5 & 0.2 to 3.3 & Current study \\
\hline
\end{tabular}

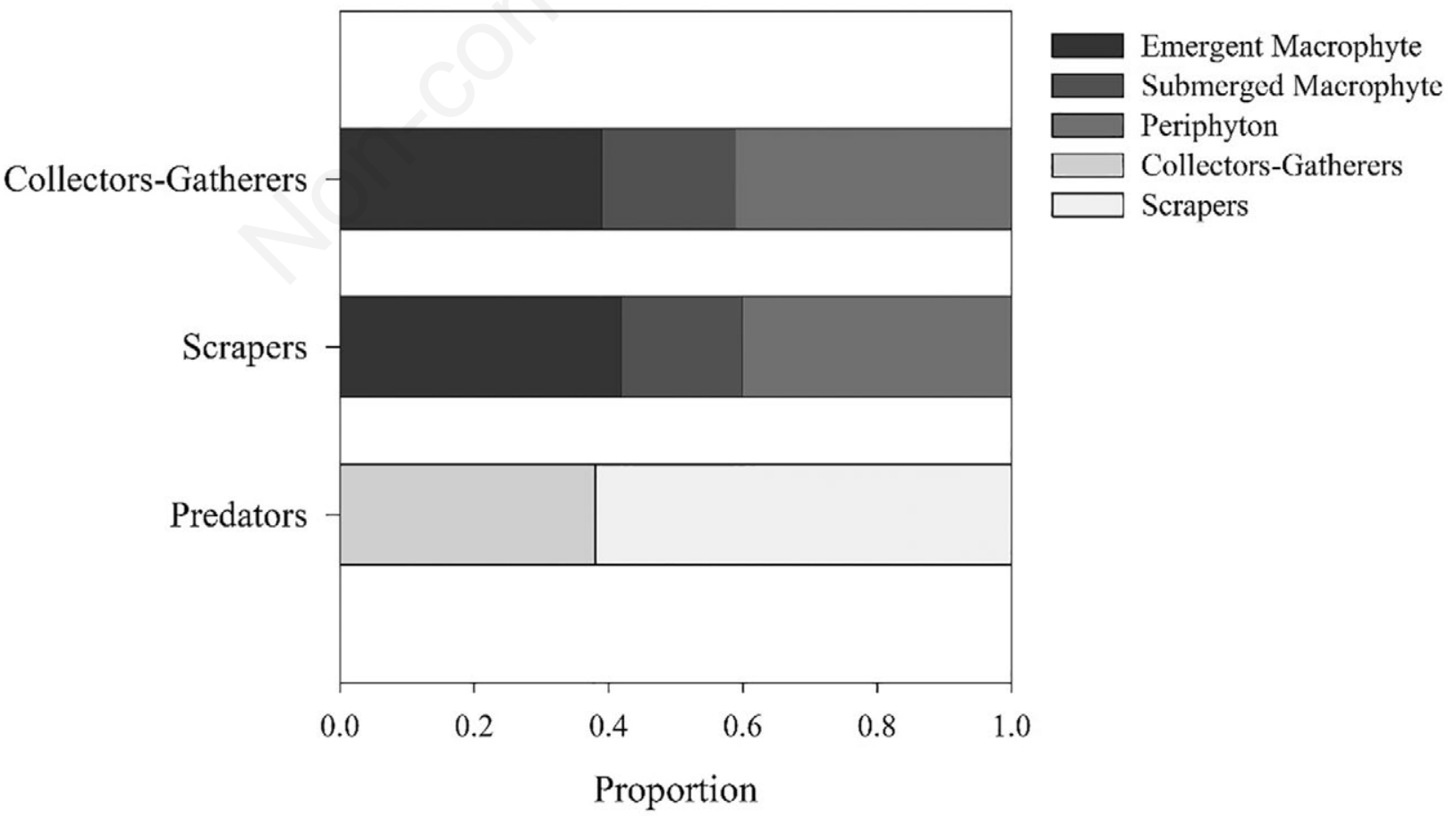

Fig. 3. Stable isotope analysis in R (SIAR) results showing proportions of food resources used by each trophic group (CollectorsGatherers, Scrapers and Predators) of aquatic invertebrates in Henrique Pond, Brasilia National Park, Federal District, Brazil. 
$\delta^{13} \mathrm{C}$ values are enriched for submerged macrophyte than for the other food sources). A study evaluating aquatic macrophytes in 19 shallow ponds in South America (Mendonça et al., 2013) suggested that the $\delta^{13} \mathrm{C}$ signal of submerged macrophytes depends on the intrinsic characteristics of the species and the availability of dissolved $\mathrm{CO}_{2}$. Because the resources required by submerged macrophytes are found almost exclusively in water and sediment, these organisms have developed morphological and physiological adaptations to overcome carbon limitation in the aquatic environment such as $\mathrm{C}_{4}$ metabolism, crassulacean acid metabolism (CAM), use of $\mathrm{HCO}_{3}$, and use of $\mathrm{CO}_{2}$ from interstitial sediment water (Pierini and Thomaz, 2004). Chappuis et al. (2017) analyzed aquatic plants from a wide range of stagnant water bodies in the Mediterranean region and also found that functional group (an intrinsic factor) is the most important factor determining $\delta^{13} \mathrm{C}$ variability. The submerged macrophyte Cabomba sp. likely uses dissolved carbon from the water column and often uses carbon from the sediment. According to Chappuis et al. (2017), these carbon sources exhibit considerable $\delta^{13} \mathrm{C}$ variability and fractioning during inorganic carbon uptake. Consequently, submerged macrophyte species exhibit less negative $\delta^{13} \mathrm{C}$ mean values since the aquatic environment generally decreases fractionation. Our analysis of stable isotope ratios for all the macrophytes of the pond did not show differences in photosynthetic metabolism $\left(\mathrm{C}_{3}\right.$ vs $\mathrm{C}_{4}$; Tab. 2), suggesting that differences in carbon source (carbon dioxide as gas or dissolved in water as bicarbonate) accounted for the difference in

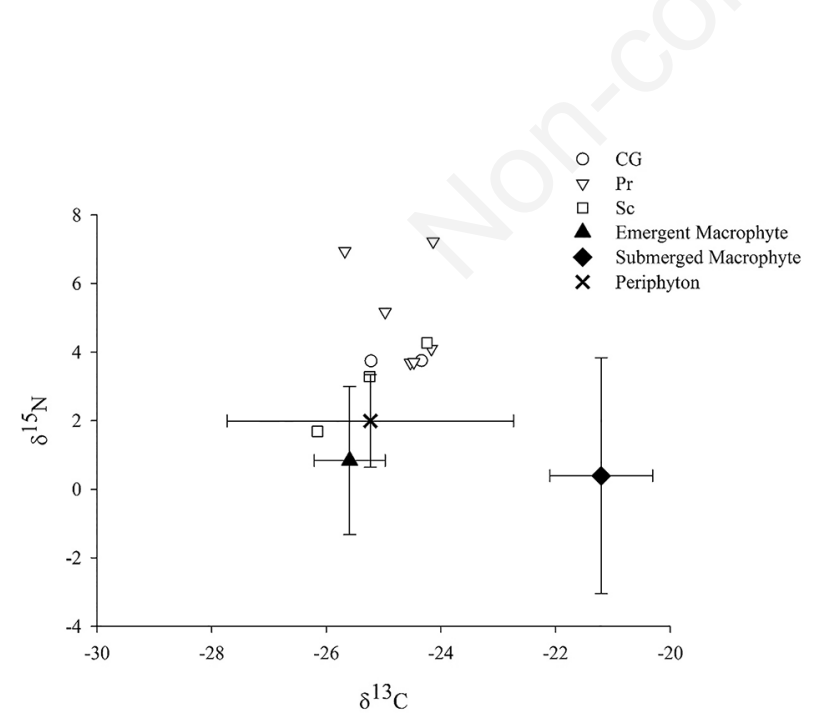

Fig. 4. Carbon $\left(\delta^{13} \mathrm{C}\right)$ and nitrogen $\left(\delta^{15} \mathrm{~N}\right)$ isotopic signatures for associated fauna and mean $( \pm \mathrm{SD})$ isotopic values for the emergent macrophyte (Cyperus sp.), submerged macrophyte (Cabomba sp.), and periphyton in Henrique Pond, Brasilia National Park, Federal District, Brazil. CG, collectors-gatherers; Pr, predators; Sc, scrapers. carbon stable isotope ratios between emergent and submerged macrophytes.

In spite of five different food sources considered in this study, their nitrogen stable isotope ratios were similar, leading to less ambiguity in the interpretation of trophic transfer through the food web and, supporting our second hypothesis (i.e., food resources present similar values of $\delta^{15} \mathrm{~N}$ ). Both of the macrophyte species studied are rooted, and they can obtain nitrogen from both the water column and sediment, whereas periphyton can obtain nitrogen from the water column and the substrate, in this case, the macrophyte. Furthermore, the studied pond is limited by nitrogen and phosphorus and, comparing macrophytes, periphyton and sediment, periphyton shows the highest concentrations of nitrogen (Alvim, 2017). There is evidence that nitrogen availability in the Cerrado is low and the nitrogen cycle is conservative (Bustamante et al., 2004). Isotope discrimination does not occur in nitrogenlimited ecosystems, and macrophyte $\delta^{15} \mathrm{~N}$ values tend to increase if the limitation is greater (King et al., 2009).

The lack of seasonal pattern in carbon and nitrogen stable isotope ratios of the basal energy sources in this study can related to subtle seasonal changes in limnological variables as only water temperature, depth, dissolved oxygen and turbidity differed between seasons (Tab. 1), This contradicts our third hypothesis (i.e., seasonality affects the carbon and nitrogen stable isotope ratios of food resources). In a remnant of the Atlantic rainforest tropical lake, Reis et al. (2016) investigated basal carbon sources and found that carbon isotope ratios were generally more negative during the dry season; however, this difference was significant only for seston ($32.6 \%$ ) and emergent macrophytes (31.3\%o; e.g., Eleocharis interstincta). The authors did not observe differences in $\delta^{15} \mathrm{~N}$ values between seasons. Nutrient concentrations and $\mathrm{pH}$ could predict the variability in $\delta^{15} \mathrm{~N}$ of macrophytes in the Pantanal floodplain and that water $\mathrm{pH}$ could predict differences of $\delta^{13} \mathrm{C}$ between periphyton and C4 plants (Alves et al., 2017). In a shallow eutrophic lake in China, the isotopic signatures for food sources varied widely $\left(-31.4 \%\right.$ o to $-14.2 \%$ of $\delta^{13} \mathrm{C}$, and $6.4 \%$ to $12.6 \%$ for $\delta^{15} \mathrm{~N}$ ), with $\delta^{13} \mathrm{C}$ and $\delta^{15} \mathrm{~N}$ values generally enriched in summer because of increased productivity (due to high temperature and irradiance levels) and compared with winter (Mao et al., 2014).

The study of Alves et al. (2017) was carried out in environments with a pH range of 6.0 to 6.9. Studies with a similar approach to ours are not common in the aquatic environments of the Cerrado, making it difficult to compare them with environments that present a $\mathrm{pH}$ range close to our study area. Although the relatively low $\mathrm{pH}$, normally found in the aquatic environments of Cerrado, favors the presence of $\mathrm{C}$ in the form of $\mathrm{CO}_{2}$, the relatively high temperatures, on the other hand, potentiate its 
diffusion into the atmosphere. Thus, the environment is conducive to carbon limitation in water, since acidic $\mathrm{pH}$ does not favor the maintenance of inorganic carbon reserves in the form of $\mathrm{HCO}_{3}{ }^{-}$or $\mathrm{CO}_{3}{ }^{2-}$ (Maberly et al., 2009). The underlying mechanisms involving $\mathrm{pH}$ changes and $\mathrm{C}$ isotopic signature need further investigation in Cerrado aquatics environments.

In the Cerrado pond analyzed in this study, periphyton and emergent macrophyte were the main food sources for collector-gatherers and scrapers, respectively, partially confirming the fourth hypothesis. This result may be due, in part, to the low $\mathrm{C}: \mathrm{N}$ ratio of periphyton, indicating its high palatability. Our finding is consistent with that of Brett et al. (2009), who reported that autochthonous sources (phytoplankton) have high nutritional quality and enhance the growth, reproduction, and lipid composition of zooplankton. Similarly, De Kluijver et al. (2015) showed that macrophytes and associated periphyton subsidize zooplankton, supporting its growth in a subtropical shallow eutrophic lake in China. Although the C:N ratio of the submerged macrophyte Cabomba sp. was lower than that of the emergent macrophyte Cyperus sp., its proportional contribution as food source was the lowest of the resources studied (18\%). This finding may be due to the greater biomass of Cyperus sp. in this environment (Fig. 2c).

The emergent macrophyte Cyperus sp. also contributed to the consumers analyzed, despite its higher $\mathrm{C}: \mathrm{N}$ ratio. Cladocera species are capable of foraging in the periphyton and have a $\delta^{13} \mathrm{C}$ signature similar to this source. In the present study, the trophic niche overlap was low, which suggests more selective feeding habits of the associated fauna and, consequently, less competition for resources. Parreira de Castro et al. (2016) found that land use changes can alter the feeding behavior of macroinvertebrates, making them more generalist and increasing trophic niche overlap.

The investigation of biogeochemical compartments (i.e., macrophytes, periphyton and sediment) of five different oligotrophic Cerrado ponds in four sampling seasons found that phosphorous concentrations are higher in periphyton than in macrophytes in these ponds (Alvim, 2017). This finding, along with the low C:N ratio observed in the present study, indicates that the periphyton of Henrique Pond is a nutrient-rich food source capable of maintaining the trophic web in this system. Based on the biogeochemical functioning of these ponds, we may also assume similar trophic interactions, indicating that the results reported here are relevant for similar environments. The elemental stoichiometry appears to be strongly related to the functional characteristics of the different primary producers in this environment.

Although we did not observe a seasonal effect on isotopic signatures, the community structure of the macrophyte-associated fauna studied (abundance of individuals) differed between seasons. In the dry season, macrophyte-associated fauna increased in abundance in both macrophytes Cyperus sp. and Cabomba sp. (Tab. $\mathrm{S} 1$ ). This result may be due to a lower water level, which decreased the size of the aquatic system and increased the concentration of organisms. In addition, the concentration of periphyton chlorophyll- $a$ in the submerged macrophyte (Fig. 2a), suggests that higher biomass of attached algae favors the greater abundance of associated fauna. Previous studies have described the relationships between macrophyte architecture and the community structures of invertebrates (Vieira et al., 2007; Thomaz and Cunha, 2010; Lucena-Moya and Duggan, 2011) and periphyton (Santos et al., 2013; Souza et al., 2015; Pettit et al., 2016). The submerged macrophyte Cabomba sp. appears to indirectly increase basal resources by increasing habitat for periphyton (primary food source) and providing shelter for the associated fauna.

Our results showed that $\delta^{15} \mathrm{~N}$ values varied from 3.7 to $7.2 \%$ for secondary consumers (predators) and from 1.7 to $4.3 \%$ for primary consumers (collector-gatherers and scrapers). This variation may be related to differences in feeding strategies and biochemical/metabolic pathways (Vander Zanden and Rasmussen, 2001; Cremona et al., 2010). Similarly, in a study that evaluated the ability of isotopic signatures to distinguish between eight taxa of tropical benthic invertebrates, $\delta^{15} \mathrm{~N}$ values varied from 6.9 to $13.3 \%$ for predators (five genera of Odonata and one genus of Hemiptera) and from 3.2 to $4.5 \%$ for shredders (two genera of Trichoptera) (Carvalho et al., 2015). The results presented here are consistent with the idea that $\delta^{15} \mathrm{~N}$ values for consumers differ between functional trophic groups, despite the high degree of variability between taxa within the same functional trophic group.

\section{CONCLUSIONS}

In this small shallow oligotrophic pond in the Cerrado, the stable isotope ratios of food sources did not vary between seasons but did differ between aquatic macrophyte life forms (emergent vs submerged). Although seasonality is an important factor in the dynamics of aquatic ecosystems of the Cerrado, it was not a determining factor in the stable isotope ratios of the food sources analyzed. The difference in carbon isotopic signatures between emergent and submerged macrophytes may be related to the different carbon sources in the aquatic environment. The nitrogen stable isotope ratios showed that they are similar, leading to less ambiguity in interpretation of trophic transfer through the food web. Periphyton and emergent macrophyte are the primary resources in this environment, possibly because of the low $\mathrm{C}: \mathrm{N}$ ratio of periphyton, indicating a higher-quality resource, and the greater biomass of emergent 
macrophyte, indicating an increase in functional diversity and a more complex environment. Although the submerged macrophyte Cabomba sp. had a lower C:N ratio and higher abundance of associated fauna and algal biomass (chlorophyll- $a$ ) than the emergent macrophyte Cyperus sp., it contributed less to the trophic web. These data indicate different trophic roles for the primary producers in this ecosystem, with the emergent macrophyte representing a primary food resource, and the submerged macrophyte providing physical structure to serve as shelter for periphyton, protection from predation, and substrate for colonization. Despite sampling restricted to one pond, our data provide empirical evidence indicating that the structure and interactions of the trophic webs in shallow oligotrophic ponds are more complex than previously thought. In addition, our results point out an increase in functional diversity and a more complex environment. The results reveal important insights into trophic web structure of a peculiar environment of the Cerrado. This type of aquatic ecosystem has not yet been extensively investigated in terms of the interactions of its very oligotrophic conditions with high richness of different aquatic groups (algae, Protozoa, microcrustaceans, and aquatic insects). Our study provides a baseline for the understanding of patterns and processes in pristine tropical environments, which are being rapidly modified by anthropogenic processes.

\section{ACKNOWLEDGMENTS}

We would like to thank the staff of the Ecosystem Ecology Laboratory of the University of Brasília and the Ecology Laboratory of Catholic University of Brasília for their assistance with field and laboratory analyses. We are also grateful for the permission granted by the Chico Mendes Institute for Biodiversity Conservation (ICMBio) to collect samples in Brasília National Park.

The first author received a scholarship from the Brazilian Federal Agency for Support and Evaluation of Graduate Education (CAPES) and the National Council for Scientific and Technological Development (CNPq) through the Graduate Program in Ecology of the University of Brasilia.

This research was financially supported by the Federal District Research Support Foundation (FAPDF)/Support Program for Centers of Excellence (PRONEX) project (no. 193.000.567/2009) and CNPq project (no. 312035/2013-6) coordinated by Dr. M.M.C. Bustamante.

\section{REFERENCES}

Alves GHZ, Hoeinghaus DJ, Manetta GI, Benedito E, 2017. Dry season limnological conditions and basin geology exhibit complex relationships with $\delta^{13} \mathrm{C}$ and $\delta^{15} \mathrm{~N}$ of carbon sources in four Neotropical floodplains. PLoS One 12:e0174499. Doi: 10.1371/journal.pone.0174499

Alvim EACC, 2017. [Variações sazonais e espaciais das concentrações elementares em compartimentos biogeoquímicos de lagoas naturais rasas do Cerrado e suas influências no funcionamento ecossistêmico].[PhD Thesis in Portuguese]. University of Brasília.

APHA, 2005. Standard methods for the examination of water and wastewater. American Public Health Association, Washington.

Arcagni M, Campbell LM, Arribére MA, Kyser K, Klassen K, Casaux R, Miserendino ML, Guevara ER, 2013. Food web structure in a double-basin ultra-oligotrophic lake in Northwest Patagonia, Argentina, using carbon and nitrogen stable isotopes. Limnologica 43:131-142.

Bini LM, Vieira LCG, Machado J, Velho LFM, 2007. Concordance of species composition patterns among microcrustaceans, rotifers and testate amoebae in a shallow pond. Int. Rev. Hydrobiol. 92:9-22.

Brett MT, Kainz MJ, Taipale SJ, Seshan H, 2009. Phytoplankton, not allochthonous carbon, sustain herbivorous zooplankton production. P. Natl. Acad. Sci. USA 106:21197-21201.

Bustamante MMC, Martinelli LA, Silva DA, Camargo PB, Klink CA, Domingues TF, Santos RV, 2004. ${ }^{15} \mathrm{~N}$ natural abundance in woody plants and soils of Central Brazilian Savannas (Cerrado). Ecol Appl. 14:S200-S213.

Carmouze JP, 1994. [O metabolismo dos ecossistemas aquáticos: fundamentos teóricos, métodos de estudo $\mathrm{e}$ análises químicas].[Report in Portuguese]. Editora Edgard Blücher/FAPESP, São Paulo: 253 pp.

Carvalho APC, Gücker B, Brauns M, Boëchat IG, 2015. High variability in carbon and nitrogen isotopic discrimination of tropical freshwater invertebrates. Aquat. Sci. 77:307-314.

Chambers PA, Lacoul P, Murphy KJ, Thomaz SM, 2008. Global diversity of aquatic macrophytes in freshwater. Hydrobiologia. 579:1-13.

Chappuis E, Seriñá V, Martí E, Ballesteros E, Gacia E, 2017. Decrypting stable-isotope $\left(\delta^{13} \mathrm{C}\right.$ and $\left.\delta^{15} \mathrm{~N}\right)$ variability in aquatic plants. Freshwater Biol. 62:1807-1818.

Cremona F, Planas D, Lucotte M, 2010. Influence of functional feeding groups and spatiotemporal variables on the $\delta^{15} \mathrm{~N}$ signature of littoral macroinvertebrates. Hydrobiologia. 647:51-61.

De Kluijver A, Ning J, Liu Z, Jeppesen E, Gulati RD, Middelburg JJ, 2015. Macrophytes and periphyton carbon subsidies to bacterioplankton and zooplankton in a shallow eutrophic lake in tropical China. Limnol Oceanogr. 60:375-385.

de Marco Jr P, Nogueira DS, Correa CC, Vieira TB, Silva KD, Pinto NS, Bichsel D, Hirota ASV, Vieira RRS, Carneiro FM, Oliveira AAB, Carvalho P, Bastos RP, Ilg C, Oertly B, 2014. Patterns in the organization of Cerrado pond biodiversity in Brazilian pasture landscapes. Hydrobiologia 723:87-101.

Doi H, 2009. Spatial patterns of autochthonous and allochthonous resources in aquatic food webs. Popul. Ecol. 51:57-64.

Eggers T, Jones T H, 2000. You are what you eat... or are you? Trends Ecol. Evol. 15:265-266. Doi: https://doi.org/10.1016/ S0169-5347(00)01877-2

Elmoor-Loureiro LMA, 1997. [Manual de identificação de 
cladóceros límnicos do Brasil].[Book in Portuguese]. Universa, Brasília.

Finlay JC, Kendall C, 2007. Stable isotope tracing of temporal and spatial variability in organic matter sources to freshwater ecosystems, p. 283-333. In: R. Michener and K. Lajtha (eds.), Stable isotopes in ecology and environmental science. Blackwell Publishing.

Fonseca BM, Estrela LMB, 2015. [Desmídias perifíticas de cinco lagoas do Distrito Federal, Brasil: II - Gêneros Euastrum Ehrenberg ex Ralfs, Micrasterias C. Agardh ex Ralfs e Triploceras Bailey].[Article in Portuguese]. Hoehnea 42:399-417.

Fonseca BM, Mendonça-Galvão L, Sousa FDR, ElmoorLoureiro LMA, Gomes-e-Souza MB, Pinto RL, Petraco P, Oliveira RC, Lima EJ, 2017. Biodiversity in pristine wetlands of Central Brazil: a multi-taxonomic approach. Wetlands 38:145-156. Doi: 10.1007/s13157-017-0964-7

France RL, 1995. Differentiation between littoral and pelagic food webs in lakes using carbon isotopes. Limnol Oceanogr. 40:1310-1313.

Fry B, 2006. Stable isotope ecology. Springer, New York: 324 pp.

IBGE, 2017. [Mapa de Biomas e de Vegetação].[Web page in Portuguese]. Accessed: 11 May 2018. Available from: http://www.ibge.gov.br/home/presidencia/noticias/2105200 4biomashtml.shtm

Iglesias C, Meerhoff M, Johansson LS, González-Bergonzoni I, Mazzeo N, Pacheco JP, Teixeira-de Mello F, Goyenola G, Lauridsen TL, Søndergaard M, Davidson TA, Jeppesen E, 2017. Stable isotope analysis confirms substantial differences between subtropical and temperate shallow lake food webs. Hydrobiologia 784:111-123.

Jepsen DB, Winemiller KO, 2002. Structure of tropical river food webs revealed by stable -isotope ratios. Oikos 96:46-55.

King L, Maberly SC, De Ville MM, Kitschke M, Gibson CE, Jones RI, 2009. Nitrogen stable isotope ratios of lake macrophytes in relation to growth form and nutrientlimitation. Fundam. Appl. Limnol. 175:307-315.

Layman CA, Arrington DA, Montañaand CG, Post DM, 2007. Can stable isotope ratios provide for community-wide measures of trophic structure within food webs? Ecology 88:42-48.

Lopes CA, Benedito-Cecílio E, 2002. Variabilidade isotópica $\left(\delta^{13} \mathrm{C}\right.$ e $\left.\delta^{15} \mathrm{~N}\right)$ em produtores primários de ambientes terrestres e de água doce. Acta Sci. 24:303-312.

Lopes CA, Manetta GI, Figueiredo BRS, Martinelli LA, Benedito E, 2015. Carbon from littoral producers is the major source of energy for bottom-feeding fish in a tropical floodplain. Environ. Biol. Fishes. 98:1081-1088.

Lucena-Moya P, Duggan IC, 2011. Macrophyte architecture affects the abundance and diversity of littoral microfauna. Aquat. Ecol. 45:279-287.

Maberly SC, Ball LA, Raven JA, Sültemeyer D, 2009. Inorganic carbon acquisition by chrysophytes. J. Phycol. 45:1052-1061.

Mao, Z, Gu X, Zeng Q, Pan G, 2014. Seasonal and spatial variations of the food web structure in a shallow eutrophic lake assessed by stable isotope analysis. Fisheries Sci. 80:1045-1056.

Marker AFH, Nusch H, Rai H, Riemann B, 1980. The measurement of photosynthetic pigments in freshwaters and standardization of methods: conclusion and recomendations. Arch. Hydrobiol. 14:91-106.
McCutchan JH, Lewis WM, Kendall C, McGrath CC, 2003. Variation in trophic shift for stable isotope ratios of carbon, nitrogen, and sulfur. Oikos 102:378-390.

Mendonça R, Kosten S, Lacerot G et al., 2013. Bimodality in stable isotope composition facilitates the tracing of carbon transfer from macrophytes to higher trophic levels. Hydrobiologia 710:205-218.

Parnell AC, Inger R, Bearhop S, Jackson AL, 2010. Source partitioning using stable isotopes: Coping with too much variation. PLoS One 5:1-5.

Parreira de Castro DM, Reis de Carvalho D, Pompeu PS, Moreira MZ, Nardoto GB, Callisto M, 2016. Land use influences niche size and the assimilation of resources by benthic macroinvertebrates in tropical headwater streams. PLoS One 11:e0150527. Doi: 10.1371/journal.pone.0150527

Peterson BJ, 1999. Stable isotopes as tracers of organic matter input and transfer in benthic food webs: a review. Acta Oecol. 20:479-487.

Pettit NE, Ward DP, Adame MF, Valdez D, Bunn SE, 2016. Influence of aquatic plant architecture on epiphyte biomass on a tropical river floodplain. Aquat. Bot. 129:35-43.

Pierini AS, Thomaz SM, 2004. [Adaptações de plantas submersas à absorção do carbono inorgânico].[Article in portuguese]. Acta Bot Brasilica 18:629-641.

R Core Team, 2015. R: A language and environment for statistical computing. R Foundation for Statistical Computing, Vienna.

Ramírez A, Gutiérrez-Fonseca PE, 2014. Functional feeding groups of aquatic insect families in Latin America: a critical analysis and review of existing literature. Rev. Biol. Trop. 62:155-167.

Reis PCJ, Martinelli LA, Barbosa FA, 2016. Basal carbon sources and planktonic food web in a tropical lake: an isotopic approach. Mar. Freshwater Res. 68:429-441.

Saigo M, Marchese MR, Wantzen KM, 2016. Sources contribution for benthic invertebrates: an inter-lake comparison in a flood plain system. Hydrobiologia 770:27-36.

Santos TR, Ferragut C, Bicudo CEM, 2013. Does macrophyte architecture influence periphyton? Relationships among Utricularia foliosa, periphyton assemblage structure and its nutrient (C, N, P) status. Hydrobiologia 714:71-83.

Sartory DP, Grobbelaar JU, 1984. Extraction of Chlorophyll a from freshwater phytoplankton for spectrophotometric analysis. Hydrobiologia 114:177-187.

Sousa FDR, Elmoor-Loureiro LMA, Mendonça-Galvão L, Pujol-Luz JR, 2014. Evaluation of a new sampling method for assessing Cladocera richness (Crustacea, Branchiopoda) in macrophyte-rich wetlands. Ann. Limnol. 50:143-153.

Souza ML, Pellegrini BG, Ferragut C, 2015. Periphytic algal community structure in relation to seasonal variation and macrophyte richness in a shallow tropical reservoir. Hydrobiologia 755:183-196.

Thomaz SM, Cunha ER, 2010. The role of macrophytes in habitat structuring in aquatic ecosystems: methods of measurement, causes and consequences on animal assemblages' composition and biodiversity. Acta Limnol. Bras. 22:218-236.

Vadeboncoeur Y, McCann K, Zanden M, Rasmussen J, 2005. Effects of multi-chain omnivory on the strength of trophic control in lakes. Ecosystems 8:682-693.

Vander Zanden MJ, Rasmussen JB, 2001. Variation in $\delta^{15} \mathrm{~N}$ and 
$\delta^{13} \mathrm{C}$ trophic fractionation: Implications for aquatic food web studies. Limnol. Oceanogr. 46:2061-2066.

Vander Zanden MJ, Vadeboncoeur Y, Chandra S, 2011. Fish reliance on littoral-benthic resources and the distribution of primary production in lakes. Ecosystems 14:894-903.

Vieira LCG, Bini LM, Velho LFM, Mazão GR, 2007. Influence of spatial complexity on the density and diversity of periphytic rotifers, microcrustaceans and testate amoebae. Fundam. Appl. Limnol. 170:77-85.

Wantzen KM, Machado FA, Voss M, Boriss H, Junk WJ, 2002. Seasonal isotopic shifts in fish of the Pantanal wetland, Brazil. Aquat. Sci. 64:239-251. 